\title{
Kinders in die erediens
}

\author{
M J du P Beukes \\ Universiteit van Pretoria
}

\begin{abstract}
Children in public worship

From a biblical and historical point of view, it is clear that the child is totally part of the church of Christ, and therefore he must assemble regularly with the congregation in public worship. From an anthropological perspective, it is clear that the child, especially in the first three phases of his life, differs so greatly from the adult, that special attention should be given to him. Consequently the liturgist sbould bear the child in mind in every church service. From time to time special church services should be held where he focuses on the child in the first phases of his life, that is the child between five en twelve years of age.
\end{abstract}

\section{RELEVANSIE VAN DIE TEMA}

Gedurende 1988-1989 het die vraag na die kind se teenwoordigheid en sy betrokkenheid in die erediens in prakties-teologiese kringe en in verskillende kerke telkens na vore gekom.

In die geledere van die Nederduitsch Hervormde Kerk van Afrika bet die Raad vir prediking en erediens indringend aan hierdie saak aandag gegee nadat uit J A Beukes se ondersoek na die erediens geblyk het dat kinders onder twaalfjaar nie die prediking van die kerk verstaan nie en nie betrokke raak by die erediens in die algemeen nie (Nederduitsch Hervormde Kerk van Afrika = NHKA 1989:313). Die Raad vir Opvoeding en Onderwys en die Raad vir Kategese van dieselfde kerk het hierdie hele problematiek na sy skakelliggaam vir jeugwerk verwys om indringend te ondersoek.

In die geledere van die Nederduitse Gereformeerde Kerk het by die Universiteit van Stellenbosch 'n proefskrif deur C D Roux 'Woordbediening aan die kind: 'n Hermeneutiese verantwoording', verskyn en by die Universiteit van Pretoria 'n 
proefskrif deur D H G Groenewald, 'Die kinderdiens in die Nederduitse Gereformeerde Kerk, met besondere verwysing na die kinderpreek'.

Die drie Afrikaanssprekende kerke in Suid-Afrika se interkerklike komitee vir jeugwerk het in 1989 'n besondere studie gewy aan die kind en die gebruik van die Nagmaal en beoog om in 1990 besondere aandag aan die verbondskind in die gemeente in die algemeen te gee.

A C Barnard het in 1988 die problematiek in hierdie verband goed verwoord. 'n Groot gedeelte van veral die oggend-erediensgangers is kinders. Hierdie kinders word egter in die meeste gemeentes tydens die erediens vergeet. Hulle teenwoordigheid maak geen verskil aan die inkJeding van die liturgie of die aanbieding van die preek nie. Alles is opgestel en word aangebied vir volwassenes. Dit het tot gevolg dat die kind nie deur die erediens aangespreek word nie. Hy raak verveeld en die gevoel van 'belangeloosheid, onbetrokkenheid en waardeloosheid ontstaan'. Dit lei verder daartoe dat die kind naderhand gewoond raak daaraan om op 'n baie vroeë stadium tydens elke erediens af te skakel.

Indien die verveling voortduur en die afskakeling 'n gewoonte word, is die volgende stap dat die kind afsydig, vervreemd raak van die erediens....Oplaas kan dit lei tot 'n negatiewe gevoel en selfs weerstand en verset teen die erediens en die prediking....Kinders word dan onder die prediking uit die kerk gepreek, en word in die erediens van die erediens vervreem.

(A C Barnard 1988:352)

Volgens Capon (1967:1) is dit doodgewoon diskriminasie wat teen die kinders in die erediens plaasvind:

There is no one in the whole Church more likely to be underestimated than the child. We have worked hard to overcome all the other distinctions between Christians in the body of Christ - distinction of colour, of class, of income and so on - but the distinction between adult and child remains firmly drawn. The child is a second-class citizen in the kingdom of God. We deny, in word and deed, that he is a full member of the Church. When we think of the Church or of Church members, we mentally exclude one of the largest groups of all - those under the age of thirteen. 


\section{VERSKI UENDE BESKOUINGS EN BENADERINGSWYSES}

Basies is daar twee grondmodelle ten opsigte van die vraag na die kind in die erediens: Die kind word beskou as 'n integrale deel van die gemeente en word as sodanig in die gemeente en in die erediens geakkomodeer of die kind word nie beskou as 'n integrale deel van die gemeente nie en word op verskillende wyses los van die gewone erediens van die gemeente geakkommodeer.

Verskillende oplossings is vir die probleem aangebied. Uit die verskillende oplossings wat aangebied word, is dit duidelik dat die antwoord nie voor-die-handliggend is nie. Slegs die belangrikste oplossings en die mees resente aanbieders daarvan sal vermeld word.

\section{Die kinders in 'n aparte erediens naas die van die volwassenes}

Die voorstanders van hierdie beskouing sien die probleem veral in die prediking. Om hierdie probleem te oorkom, word verskillende oplossings aangebied: 'n Volledige aparte erediens vir die kinders terwyl die volwassenes se erediens aan die gang is. Hier word nie net gedink aan 'n aparte preek vir die kinders nie, maar aan 'n eie kinderliturgie. 'n Ander moontlikheid is dat die kinders saam met die volwassenes in die erediens vergader en sodra die preek begin, verlaat hulle die erediens en gaan na 'n ander lokaal vir hulle eie preek.

Vanuit opvoedkundige kringe was dit veral N T van Loggerenberg (1982) wat sterk pleidooie gelewer het vir aparte kinderdienste. Die ontwikkelingspeil van die kind sien hy as die basiese motivering vir sy standpuntinname.

Die ontwikkelingspeil van die kind en die inkleding van die gewone erediens lei tot 'n negatiewe belewenis van die erediensgebeure.

Opvoedkundige navorsing toon egter dat 'n kind wat aanhoudend blootgestel word aan waarhede wat hy nie begryp nie, op die dag wanneer hy ryp genoeg is om dit wel te verstaan, geen betekenisvolle reaksie toon nie: eerder 'n verveelde houding omdat die oorbekende gegewens dan vir hulle trefkrag verloor het. Is hierdie eerste jare wat 'n kind dikwels verveeld in die erediens sit, nie miskien die rede waarom baie kinders later heeltemaal onverskillig staan teenoor die erediens nie?

(Van Loggerenberg 1982:37)

Met die problematiek van die hermeneutiek wat Cornelia Roux, soos Lategan, verstaan as die 'verantwoorde weg waarlangs die verkondiging met vertroue van teks na 
preek kan beweeg', wou Roux ondersoek instel na die effektiwiteit van die Woordbediening aan die kind met die oog op 'geloofsgroei te midde van 'n reële veranderde wêreld' (Roux 1988:6). Na ondersoek van die kind se religieuse potensiaal en 'n empiriese ondersoek na Woordbediening aan kinders in die Nederduitse Gereformeerde Kerk, stel sy die volgende werkhipotese as haar ideaal: Die daarstel van 'n hermeneutiese raamwerk vir Woordbediening aan die kind wat behoeftes van die kind ten volle in ag neem ( $\mathrm{d}$ behoeftes voortspruitend uit sy religieuse potensiaal, ontwikkeling en ervaring) en die appel van die Woord tot hom rig, om sodoende Woordverkondiging aan die kind te optimaliseer en by te dra om die afstandsprobleem te oorbrug (Roux 1988:10).

In die eerste gedeelte van haar proefskrif gee Roux besonder aandag aan verskillende teorieë met betrekking tot die kind. Gedurende die laaste aantal jare is baie studies oor die kind se religieuse ontwikkeling onderneem. Oor die algemeen is aanvaar dat die kind se psigologiese, kognitiewe en religieuse ontwikkeling hand aan hand gaan. Roux neem in hierdie verband sterk standpunt in teen Jean Piaget en Ronald Goldman se teorieë oor kinderontwikkeling. Piaget oordeel dat kenmerkende aspekte wat die kind se denke op 'n bepaalde stadium vertoon, die norm moet wees vir die hantering van die kind. Hy kategoriseer kinders volgens hulle intellektuele vermoeẽ in bepaalde stadia en neem dit as vertrekpunt vir alle inhoude wat aan hulle oorgedra moet word (Roux 1988:16, 17). Goldman het na ondersoek sy basiese stelling gemaak, naamlik dat alle religieuse denke deur formele denke vooraf gegaan word. Dit lei tot sy volgende stelling, naamlik 'dat kinders in godsdiens geleer moet word wat hulle kan verstaan en kognitief sal kan hanteer'. Goldman deel kinders in drie fases in: die voor-religieuse fase 0-5 jaar, die subreligieuse fase 7-11 jaar en die persoonlik-religieuse fase 12 jaar en ouer. Volgens hom het die kind in die voor-religieuse fase geen gevoel of denke van die godsdiens nie. Selfs in die sub-religieuse fase oordeel hy dat die kind nog steeds nie oor die religieuse of godsdienstige kategorieë beskik om met godsdiensonderrig te begin nie. Slegs kinders oor twaalf is volgens hom in staat om 'normaal' en formeel oor God te dink (Roux 1988:18).

Roux sluit baie sterk aan by Montessori, Cavaletti en Berryman.

Maria Montesorri het in die begin van die dertigerjare besondere aandag aan die religieuse potensiaal van die kind gegee. Sy stel nie die geestelike aspekte sonder meer met die psigologiese en kognitiewe gelyk nie. Sy oordeel dat die kind self tot 'n diep geestelike lewe in staat is. Die kind beskik oor 'n inherente religieuse potensiaal en openbaar van kleinsaf 'n besondere verhouding met God. Hierdie 'natuurlike' wat deel is van die kind, sien sy as 'n Godgegewe gawe. 'Just as the education of physical and pshycic life is nothing else than co-operation with the 
natural forces of growth, so the supernatural education is nothing else than cooperation with God's grace, which provides the real urge to true process of growth in the divine life' (Roux 1988:32).

Montessori oordeel verder dat die kind geleentheid gegee moet word om teen sy eie tempo godsdienstig verder te ontwikkel.

Daar word veral erkenning gegee dat die kind 'n Godgegewe gawe is wat ook tot 'n diep geestelike geloofslewe in staat is. Die besondere aanbieding van Bybelse waarhede waar die kind se behoeftes aangespreek word, bly een van die belangrikste aspekte van Woordbediening aan die kind. Die aansluiting by Montessori hou in dat die kind vanaf ' $n$ baie jong ouderdom aan die verskillende aspekte van die erediens blootgestel behoort te word.

(Roux 1988:32)

Net soos Montessori het Sofia Cavaletti na deeglike navorsing geoordeel dat die kind van nature ' $n$ religieuse potensiaal het en dat hierdie potensiaal ten volle ontwikkel moet word. Die kind het volgens haar vanaf drie tot ses jaar reeds 'n sodanige godsdienstige aanvoeling dat hy met die regte begeleiding in die regte verhouding met God kan staan. Na navorsing met kinders uit Rome, Chad, Brasilië, Meksiko, Kanada en die Verenigde State van Amerika is haar tese bevestig, naamlik dat religieuse potensiaal sluimerend in alle kinders is en nie beperk is tot 'n spesifieke kultuurgroep nie (Roux 1988:33-35).

Jerome Berryman, 'n leerling van Cavaletti, het by sy leermeester aangesluit en ook beklemtoon dat die kind van kleins af 'n religieuse potensiaal het. Die ontwikkeling van hierdie potensiaal moet sterk binne die vermoë van die kind geskied. Dit moet ook geskied op 'n besondere wyse: 'Secular models can teach children to speak the language of science, but it takes a special kind of method to learn to speak to be a Christian' (Roux 1988:36). Hierdie 'special kind of method' noem hy 'religious language'. Roux het dit vertaal met 'praktiese Bybeltaal' (Roux 1988:37). Hierdie besondere verkondiging aan die kind op 'n besondere wyse vra ook 'n besondere persoon on dit te verkondig.

To teach the art of using religious language may require a master of that art. This means that the youngest and most vulnerable of human 
beings need to have the wisest and most experienced ones to teach them. We often turn this upside down in the church of modern times.

(Roux 1988:36)

Om vas te stel of die gemiddelde kind onder twaalfjaar oor 'n inherente religieuse potensiaal beskik wat nie noodwendig in 'n direkte een tot een verhouding met sy psigologiese en kognitiewe ontwikkeling staan nie, het Roux 'n informele empiriese ondersoek in die Verenigde State van Amerika en hier ter lande geloods. Hierdie ondersoek het uit twee komponente bestaan: die nie-dogmatiese interkulturele aanbieding van 'praktiese Bybeltaal' en die ontwerp en aanbieding van 'n kleutergodsdienskursus gebaseer op 'praktiese Bybeltaal' en spesifiek toegepas op Gereformeerde beginsels (Roux 1988:38). Die doel was om vas te stel of die Afrikaanssprekende kind dieselfde reaksie toon op die aanbieding van 'praktiese Bybeltaal' as byvoorbeeld Amerikaanse kinders waaroor daar al soveel gerapporteer is. Om haar doel te bereik het sy in 1987 'n kursus oor 'My oop gemoed', ontwerp. Hierdie kursus bestaan uit drie afdelings, naamlik:

- 'n Afdeling wat bestaan uit verhale uit die Ou en Nuwe Testament;

- 'n Afdeling wat handel oor die verskilende kerklike feesdae;

- 'n Afdeling wat bestaan uit ses gelykenisse uit die Nuwe Testament.

Die kursus is sover as moontlik 'prakties' aangebied deur die kind se gevoel-, ouditiewe en visuele sintuie by die aanbieding te betrek. Die kursus is in die vorm van sestien sessies oor 'n tydperk van twee maande aan drie en twintig voorskoolse kinders by ' $n$ kleuterskool in Stellenbosch aangebied. Na afhandeling het Roux (1988:40) geoordeel dat:

Die kinders het elkeen volgens sy eie vermoeë die Bybelstof geïnterpreteer en kon dus daardeur aan die aanbieder 'n aanduiding van die religieuse potensiaal gee. Gegewe die opvallende ooreenkoms wat daar ook in die Suid-Afrikaanse konteks gevind word met betrekking tot die kind se reaksie op praktiese Bybeltaal, is die afleiding geregverdig dat die Afrikaanssprekende kind geen uitsondering is nie. Die besondere siening van Cavaletti en Berryman sou derhalwe ook op die Suid-Afrikaanse kind van toepassing gemaak kon word. 
Na genoemde empiriese navorsing neem Roux (1988:41) die volgende standpunte in:

Ten opsigte van die religieuse ontwikkeling van die kind:

(a) die jong kind (3-6 jaar) alhoewel hy nog 'n sterk egosentriese houding teenoor godsdiens openbaar, kan 'denke' en 'n 'gevoel' teenoor godsdiens ontwikkel;

(b) die kind van 7-13 jaar openbaar reeds 'n verhouding teenoor God, waarin God byvoorbeeld sterk as 'n 'Vriend' figureer;

(c) die kind se ervaringswêreld is van belang vir sy religieuse ontwikkeling en veral ook vir die uitbouing van sy religieuse potensiaal.

Ten opsigte van die sogenaamde religieuse potensiaal die volgende:

(a) die kind, as 'n Godgegewe gawe, openbaar reeds van kleins af 'n besondere verhouding teenoor God en kan daarom ook aanspraak maak op die erkenning daarvan deur die volwassene;

(b) die kind moet aanspraak maak op bevatlike korrekte Bybelse stof, aangebied in 'n ondersteunende atmosfeer met 'n positiewe benaderingswyse;

(c) die kind behoort in die erediens korrekte Bybeltaal (visuele voorbeelde) vanuit die Skrif te ontvang om verdere geloofsgroei te bevorder.

Deur middel van 'n hermeneuties-empiriese analise in vyf Nederduitse Gereformeerde gemeentes met vyftig kinders tussen die ouderdom van 7 en 13 jaar, stel Roux vas dat predikers in die Nederduitse Gereformeerde Kerk oor die algemeen nie 'n hermeneutiese raamwerk vir kinderprediking gebruik nie en waar dit wel gebruik word, word of die teks of die kind, of albei, geweld aangedoen (Roux 1988:46).

$\mathrm{Na}$ die vasstelling van die probleem ontwerp sy 'n hermeneutiese raamwerk wat die kind optimaal in Woordbediening kan akkommodeer en wat die afstandsprobleem tussen teks, prediker en kind tot die minimum beperk. 
Hierie ontwerpte hermeneutiese model noem sy die 'kwadrantmodel'. In die model word vier komponente onderskei, naamlik die Bybelteks (BT), die Bybelperspektief (BP), die Kinderervaring (KE) en die Appel (A).

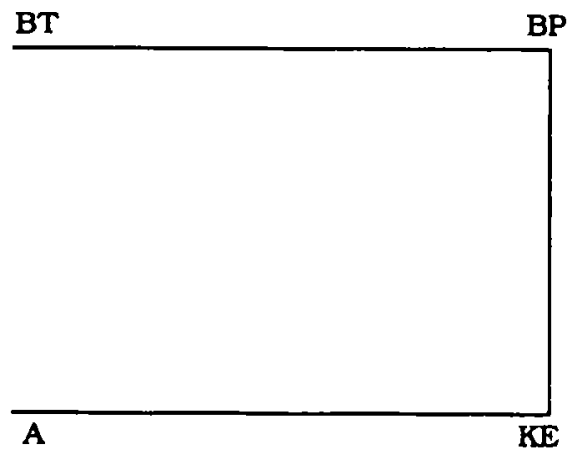

$\mathrm{Na}$ deeglike eksegese van die Bybelteks (BT), die vasstelling van die skopus en die plasing van die teks en die skopus in die lig van die breër teologiese raamwerk (BP), word, met die kind se ervaring (KE) in die oog, die preek uitgewerk en 'n bepaalde appèl (A) tot die kind gerig. In die model word nie 'n vaste beginpunt gegee nie. Dit het tot gevolg dat, in die praktiese preek, by enige van die komponente begin kan word. In die uitwerk en die aanbieding van die preek, speel elementarisering en die in-ag-neem van die kind se religieuse potensiaal 'n sentrale rol. Roux se model beteken dat die prediker nie net rekening moet hou met die kind of net met die teks of net met die konfessie nie, maar met elke komponent wat vir sinvolle prediking noodsaaklik is.

Uit Roux se opmerkings oor 'oopgesprek', het dit duidelik geblyk dat sy oordeel dat die kind alleen tot sy volle reg op godsdienstige vlak kan kom, en haar hermeneutiese beginsels van toepassing gemaak kan word, in 'n erediens wat afsonderlik van die volwassenes gehou word (Oopgesprek, SAUK 1989).

\section{2 'n Afsonderlike kerk vir kinders}

Doris A Freese (1982) het geoordeel dat dit nie voldoende is om kinders net in 'n aparte erediens te betrek of vir hulle 'n afsonderlike preek te hou nie. Sy wil 'n feitlik afsonderlike kerk vir die kinders ontwerp wat naas die volwasse kerk funksioneer. In hierdie strategie gee sy vir die erediens plek as deel van die kerk se totale bemoeienis met die kind. Sy voer die volgende as motivering aan: 
- The first reason has to do with the child himself. He simply is not an adult. He requires activities different from those of an adult.

- A second reason for having a church time geared to children lies in the nature of the adult service itself. Any minister will admit that the service focuses primarily on adults and their needs and their concerns. The entire service assumes adult intellects, adult participation, and adult response.

(Freese 1982:11)

Freese stel dat 'n kinderkerk nie die volgende is nie:

- slegs kategese in ' $n$ ander vorm en op 'n ander tyd;

- 'n mini-volwasse erediens;

- 'n byeenkoms van al die gemeentekinders met die doel om hulle besig te bou terwyl hulle ouers in die erediens is;

- 'n geleentheid waartydens die kinders van die gemeente geěvangeliseer word.

Die kinderkerk is 'a program geared to the child's level so he truly worships the Lord with understanding and has opportunity to actively participate' (Freese 1982:10).

Die kinderkerk word op ' $n$ bepaalde wyse ingerig: Die kinders van die gemeente kom in 'n grootgroep byeen. Die voorganger 'through some interest-holding method introduce the key Bible truth for the session' en gee aan elke ouderdomsgroep 'n bepaalde opdrag. Die verskillende ouderdomsgroepe werk in hulle kleingroepe onder leiding van ' $n$ volwassene hulle opdragte uit. Die kleingroepsessie is ' $n$ leergeleentheid waar bepaalde doelwitte moet realiseer, maar is tegelyk 'n oefensessie met die oog op die grootgroepgebeure daarna. In die grootgroep vind hierna die 'worship' plaas.

Elements to be included are a call to worship (quiet music, a special song, or a Bible verse recited together), music (both singing and any special music), prayer (a child or a leader may pray), offering and dedication, Scripture (shared by one of the groups) and devotional (shared by a group or a teacher).

(Freese 1982:39) 
23 Kinders in die erediens saam met die res van die gemeente

In die jongste tyd was dit veral Vrijlandt (1987:338), Coetzee (1984:8), Barnard (1988:123) en Groenewald (1989) wat gepleit het vir die behoud van die kind in die gewone erediens saam met die ander lidmate van die kerk. Hulle maak in die besonder gebruik van teologiese argumente om afsonderlike eredienste vir kinders af te wys. Veral Groenewald het 'n besondere bydrae in die debat gelewer deur die tot op datum redelik onbekende en onverwerkte stof in sy proefskrif te verwerk.

Samevattend oordeel Groenewald soos volg oor die Bybelse gegewens in verband met hierdie tema:

Kinders is van die begin af aanvaar as deel van die gemeente, hulle is gedoop en onderrig as kinders van die verbond, hulle is betrek by en het deel gehad aan die amptelike godsdiensoefening. So is hulle dan ook kulties begelei vanaf geboorte en daar is geen bewys dat hulle op enige lewensstadium by enige kultiese handeling uitgesluit is nie. Die verbond het natuurlik hierin 'n groot rol gespeel. Dit was korporatief en inklusief van aard en was sterk aan die kind as nageslag en erfgenaam van God se verbondseën gebind. Dit het egter ook die verbondsverpligtinge op die kind gelé. Hy moes dit getrou nakom en dit kon net geskied met getroue begeleiding deur die volwassene. Dit het uit die aard van die saak ook deelname deur die kind beteken. Nêrens is 'aparte' deelname aan die godsdiens geskep nie.

(Groenewald 1989:28)

Hoewel die kinders aanvanklik net deur die ouers godsdienstig onderrig is, was hulle van die vroegste tyd af ten volle betrokke by die gemeentelike erediens (Groenewald 1989:36). Louw verwys na Cyprianus wat in ongeveer $250 \mathrm{n}$ C melding gemaak het van 'n gereelde gebruik van die kerk om kinders te doop (Louw 1973: 10). Die Apostoliese Konstitusies gee opdrag dat die kinders ook Nagmaal moet gebruik. Augistinus het die gebruik van Nagmaal deur kinders as noodsaaklik geag (Aalbers 1971:18). Op grond van die besondere plek van die doop en die Nagmaal in die gemeentelike lewe, oordeel Bottermann dat die kinders volwertiger Teil der Kirchengemeinde angesehen wurden (Groenewald 1989:38). Die Rooms-Katolieke sakramentalisme het daartoe aanleiding gegee dat die kinders van die Nagmaal geweer is en al hoe minder betrokke was by die erediens. Die besondere 'heiligheidsgedagte' van die Rooms-Katolieke Kerk het daartoe gelei dat alle kinders die erediens moes verlaat sodra die Nagmaalbediening begin het. In die kloosters, aan 
die anderkant, het die kinders ten volle deelgeneem aan die erediens. Teen ongeveer $1400 \mathrm{n} C$ was dit algemene gebruik dat die bywoning van die erediens ' $n$ deel van die kinders se kategese was.

Luther het klem gelê op die eenheid tussen kerk, skool en ouerhuis. Die gesin en die skool sien by as die instansies wat verantwoordelik is vir die godsdiensonderrig. Die kerk was verantwoordelik om 'door haar catechismusprediking nadere uitlegging te geven' (Bijlsma 1962:66). Hy het geěis dat daar in die prediking met die kind rekening gehou moet word. Calvyn het 'n besondere kategese deur die kerk voorgestaan. Hy het, net soos Luther, die kinders by die kategismusprediking betrek. Kategismusprediking is volgens H D A du Toit oorspronklik bedoel vir kinders (Groenewald 1989:52). In die tyd van die Reformasie het sporadiese kinderdienste voorgekom. J $E$ van Gunzburg het bepaal dat 'n kinderdiens op 'n Sondagmiddag in elke gemeente gehou moet word. Onder leiding van Zwingli het kinderdienste in Switserland algemeen geword. Daar is onder andere elke Sondag tussen elfuur en twaalfuur in Grösmunster 'n diens net vir kinders gehou. Kinderpreke het op vroeë stadium algemeen in Lutherse kerke voorgekom.

Tot 1618 het die kategese in Nederland hoofsaaklik bestaan uit kategismusprediking. Tydens die Sinode van Dordt het daar verandering gekom. Die kategese sou voortaan deur kerk, skool en ouers waargeneem word. Op die Sinode word ook besluit dat die predikante moes voortgaan om gereeld kategismuspreke te hou 'behoorlijk kort en voor het begrip der volwassenen en der jongelui gepast' (Hagenbeek 1947:32).

Die Piëtiste en die Rasionaliste met hulle klem op die gevoel en die verstand, het in teenstelling met die Reformatore, vir die kind ruimte geskep in 'n erediens naas die gewone erediens (Groenewald 1989:61).

In Suid-Afrika het afsonderlike kinderdienste baie sporadies in die Gereformeerde Kerke en die Nederduitsch Hervormde Kerk van Afrika voorgekom. Aan die begin van die eeu het afsonderlike kinderdienste veral in die Nederduits Gereformeerde Kerk in die Vrystaat voorgekom en slegs sporadies in die ander provinsies in hierdie kerk. Gedurende die periode voor 1966 het kinderdienste in die Nederduitse Gereformeerde Kerk voorgekom sonder dat daar enige diepgaande besinning op die sinodes oor hierdie saak plaasgevind het. Uiteindelik het die 'aparte kinderdiens in die Nederduitse Gereformeerde Kerk misluk' (Groenewald 1989: 131). Die belangrikste redes vir hierdie mislukking is volgens Groenewald die ferm standpunt wat die teologiese fakulteite daarteen ingeneem het in die persone van H D A du Toit en D W de Villiers en die deeglike besinning en verantwoordelike besluite wat deur die Algemene Sinode geneem is (Groenewald 1989:130). Die amptelike beleid van die Nederduitse Gereformeerde Kerk in verband met die kind 
in die erediens, word weergegee in hulle Algemene Sinode besluit van 1978 wat in 1986 herbevestig is. Vanweë die belangrikheid van hierdie besluit word dit volledig angehaal.

- Dat huisgesinne soveel as moontlik aangemoedig word om as 'n eenheid na die huis van die Here te kom en ook, waar immer moontlik, in dieselfde bank sit.

- Dat eredienste so ingerig moet word en die prediking so aangebied moet word dat dit rekening hou met al die ouderdomsgroepe in die gemeente.

- Dat nie net die broers en die susters nie, maar ook die kinders meer aangespreek moet word tydens die prediking.

- Dat daar by geleentheid (soos byvoorbeeld met die opening of afsluiting van die kategese of met die biddag vir die kategese en/of die studerende jeug) 'n erediens waarin die klem van die Woordbediening in die besonder op die kinders val, gehou moet word. Dit kan 'n gesinsdiens wees waar daar dan in die teenwoordigheid van die ouers en die hele gemeente oor 'n teks of 'n Skrifgedeelte gepreek word waarby die kinders besondere belang het. Dit kan ook die vorm van 'n 'leerkerk' aanneem waaroor basiese waarhede gepraat word.

- Dat aparte kinderdienste, waar vir die kinders afsonderlik en gelyktydig met die erediens of in die plek van die erediens gepreek word, nie goedgekeur kan word nie.

- Dat kinderdienste gelyktydig met Nagmaaldienste ook nie aan te beveel is nie en gemeentes versoek word om liewer soos gewoonlik kategese te hou. Dit kan so gereël word dat die personeel maklik nog die Nagmaalsdiens kan bywoon.

- Dat kategese wat gelyktydig met of gedeeltelik met die erediens gehou word, ten sterkste afgekeur word. Daar moet steeds duidelik onderskei word tussen erediens en kategese.

- Dat die kundige en versigtige gebruik van visuele hulpmiddels tydens dienste nie verkeerd is nie, mits die waardigheid van die kansel en erediens in ag geneem word, daar binne perke gebly word en die beelde steeds Skiftuurlik-eksegeties verantwoord is binne die bepaalde verband.

- Dat die leraars sal poog om met elke preek so bevatlik te preek dat die kinders ook iets sal ontvang vir hulle geestelike opbou. 
- Dat 'n middagkinderdiens waartydens doop bedien word, ook nie goedgekeur kan word nie, aangesien die sakrament in die teenwoordigheid van die gemeente bedien moet word. Ook hierdie diens moet liewer as 'n gesinsdiens ingerig word, selfs al sou die prediking op die kinders afgestem wees.

- Dat, mits praktiese omstandighede dit onmoontlik maak vir kinders om die gewone Pinksterbyeenkomste by te woon, gemeentes versoek word om dit baie sterk te oorweeg om twee reekse kinderbyeenkomste tydens Pinkster (vir kleiner en groter kinders) te hou.

(Nederduitse Gereformeerde Kerk 1978:448-449)

\subsection{Evaluering}

Met die oog op die daarstelling van 'n eie benaderingstrategie ten op sigte van die kind in die erediens, is dit nodig om kortliks die benaderingsrategie van Roux, Freese en Groenewald te evalueer.

Roux, met die daarstelling van haar eie hermeneutiese proses om 'n preek vir kinders te ontwerp, het 'n enorme groot bydrae gelewer. Net soos Freese wil sy ten volle rekening hou met die kind in die erediens. Dit het daartoe gelei dat sy op 'n heel wetenskaplike wyse vasgestel het dat die kind van 'n baie vroeẽ stadium in sy lewe oor 'n bepaalde religieuse potensiaal beskik en dat die prediking in 'n bepaalde vorm gegiet, ' $n$ bepaalde effek op die kind het. In haar bestudering van die kind begin sy egter op 'n ander plek as wat teoloë gewoonlik begin met hulle besinning oor die mens. Die teoloog vra altyd in die eerste plek na die Bybelse antropologie voordat hy die data van ander wetenskappe op die tafel sit. In die bestudering van die kind, behoort Roux ook die gegewens van ander afdelings van die sielkunde en die opvoedkunde te benut soos onder andere die gegewens oor die faseologie. Vanuit die teologie word aanvaar dat die kind in homself geen vermoe het om te glo nie nie, maar deur die genade van God in Jesus Christus deur die Heilige Gees hierdie vermoë ontvang het. Dit wat Roux wetenskaplik bewys het, is vir die kerk 'n reeds aanvaarde gegewene. Die besondere waarde van Roux se navorsing is dat dit wat mense altyd ten opsigte van hierdie saak bewys wil hê, wel bewys het. Twee van die hoofkomponente ter sprake by 'n studie oor hierdie tema, naamlik die kind en die prediking, het Roux redelik goed in die oog gehad. Die bestudering van die ander hoofkomponent, naamlik die erediens as sodanig, het sy nooit laat funksioneer nie. 
Freese laat alle ter sprake komponente ter syde en laat haar hele strategie geheel en al deur die kind bepaal. Nog die Bybelse nd̀g die historiese of die besinning oor die wese van kerkwees of erediens, kom by haar aan die orde.

Groenewald het die Bybelse en die historiese stof goed tot hulle reg laat kom. Ook die relevante gegewens ten opsigte van die erediens het hy goed aan die orde gestel. Hy laat egter na om die kind met sy besondere aard in die oog te kry.

\section{EIE BENADERINGSWYSE}

In die Praktiese Teologie is verskillende benaderingswyses moontlik: die teologiese, die historiese, die prakties-empiriese, die bipolere en die teologies-historiespraktiese werkwyse (Beukes 1987:8-9). Die laaste werkwyse, wat ook die multidimensionele werkwyse genoem word en ook die algemeen aanvaarde werkwyse van praktiese teoloe is, hou in: Die vraagstuk word ondersoek met in agneming van teologiese, historiese en empiriese gegewens. Dit beteken die vraag sal gevra moet word: wat sê die Bybel oor die kind in die erediens, wat sê die geskiedenis oor die kind in die erediens en hoedanig is die kind en hoedanig ervaar hy die erediens? Die omvattende, alle komponente in die oog hou strategie, soos vervat in R A Kruger se kurrikulumteorie (Kruger 1980), sal miskien in 'n verwerkte vorm die modus operandi bied vir die sinvolste benaderingswyse van die kind se plek in die erediens. Dit beteken die volgende sake sal ondersoek moet word:

- Die wese van die erediens, Bybels en histories gesien met die oog op die kind se betrokkenheid in die erediens;

- Die plek van die kind in die gemeente en die erediens Bybels en histories gesien;

- Wie is die kind in die erediens?

- Hoe lyk die erediens?

- Hoe moet die erediens ingerig word om die kind sinvol te akkommodeer?

3.1 Bybels-historiese perspektiewe oor die plek van die kind in die kerk en die relevansie daarvan vir die kind se teenwoordigheid in die erediens

Volgens die Ou Testament rig God 'n verbond op met die volk Israel en die kinders is 'n integrale deel van hierdie verbondsvolk (Deut 29:10, 11, 12).

Die kinders het in die ou verbond hoegenaamd nie 'n afsonderlike plek naas die van die ouers beklee nie. Hulle het in die verbondslewe grootgeword en het deel gehad aan die verbondstekens net soos die 
volwassenes. Die Here het ook nie die kinders oor die hoof gesien nie, maar $\mathrm{Hy}$ het hulle ook in sy diens gebruik en verbondseise aan hulle opgele wat ook hulle moes nakom.

(Viljoen 1989:3)

Die kinders se besondere deel wees van die volk van God word veral uitgedruk deur hulle teenwoordigheid wanneer die volk byeengekom het en hulle deelname aan die Pasga (Viljoen 1989:4). Nieteenstaande die kind se besondere deel wees van die volk van die Here, het die Joodse Skrifgeleerdes hulle geheel en al as onmondiges beskou (Louw 1973:29) en hulle gevolglik van die tempeldiens en later van die sinagogediens uitgesluit.

Die kind se deelhê aan God se genadegawes en sy deel wees van die gemeente van Christus, moet in die Nuwe Testament geheel en al gesien word vanuit die Christusgebeure. Die kind se besondere plek in die koninkryk van God word nerens beter sigbaar verwoord as deur die doop nie. Die kinderdoop is juis geregverdig omdat die kind van gelowige ouers 'net soos volwassenes in die verbond van God en sy gemeente ingesluit is'. In die lig van die Nuwe-Testamentiese boodskap glo die kerk dat: God ook die vader van die kinders is, dat Jesus Christus ook vir die kinders se sonde betaal het en ook vir hulle die dood oorwin het, dat die Heilige Gees ook ten volle aan die kinders gegee is en dat hulle ook deel is van die gemeente. Hierdie feite is die waarskynlike rede waarom die vroeẽ Christelike kerk sonder meer aanvaar het dat die kinders deel is van die gemeente en gaan Paulus onder andere uit van die veronderstelling dat die kinders ook teenwoordig was as sy briewe in die gemeentes voorgelees word.

Op grond van die verbond oordeel Barnard (1988:357) dat die kind deel is van God se volk en daarom saam met die volwassenes in die erediens teenwoordig moet wees.

God werk nie slegs met los enkelinge nie, maar met die mense in hulle verbande, met die opeenvolging van die geslagte van die gelowiges. Die kind leef in die dampkring van die verbond, met al sy beloftes, seëninge en verpligtinge. Die verbond is verder die grond en die basis vir die erediens. In die erediens word die verbond vernuwe en herbeleef, die beloftes van die verbond word steeds toegesê en gelowiges word opgeroep om daaruit te lewe. Die kind is deel van die verbond, die erediens geskied op grond van die verbond en vernuwe die verbond. Nou spreek dit vanself dat die kind moet deelneem aan die erediens. 


\section{Verskeidenheid en eenheid}

In die Bybel word alles nie sonder meer gelyk gestel nie. Die Bybel hou rekening met die diversiteit maar ook met die eenheid. Die eenheid speel veral 'n belangrike rol as dit kom by die beskrywing van die funksionering van die gemeente en die huisgesin. Die kind het 'n besondere plek in die huisgesin gehad en was 'n onlosmaaklike deel van die huisgesin. Die ouers het die verantwoordelikheid gehad om die kind op te voed en om in die besonder die verbondsverantwoordelikheid vir hom te leer. Die huisgesin was verder geroepe om as 'n eenheid die Here te dien.

Die dooplidmaat se lid wees van die kerk van Christus vind sy vertrekpunt en inhoud in die verbond van God waarin die verbondsjeug ten volle ingesluit is....Elke verbondskind is 'n gawe van God aan die verbondsouers, en so vorm die gesin as verbondsgemeenskap die grondslag vir die posisie van die dooplidmaat. Die bediening van die dooplidmaat geskied gevolglik hoofsaaklik vanuit sy verbondenheid aan die gesin.

(Venter 1989:1)

\subsection{Historiese gegewens}

Uit die historiese gegewens soos reeds hierbo genoem kan die volgende afleidings gemaak word:

- In die vroeë Christelike Kerk kon die kind deelneem aan alles wat in die erediens plaasvind.

- Die Rooms-Katolieke Kerk se sakramentsleer het daartoe aanleiding gegee dat die kind uit die erediens uitgesluit is.

- Die Reformatore het die kind weer ten volle deel gegee aan die erediens, behalwe deelname aan die Nagmaal. Die Reformatore het die kategismusprediking in die besonder ingestel as prediking vir die kind en baan op hierdie wyse die weg vir prediking wat in die besonder gerig is op kinders in die gewone erediens waar die res van die gemeente ook teenwoordig is.

- Die Piētiste en die Rasionaliste het begin om afsonderlike eredienste vir die kinders te hou.

- Die amptelike beleid van die drie Afrikaanssprekende kerke in Suid-Afrika was en is om die kind in die gewone erediens saam met die res van die gemeente te betrek alhoewel die Nederduitse Gereformeerde Kerk voorsiening maak vir afsonderlike 'kinderpreke' onder bepaalde omstandighede. 
3.4 Die erediens se besondere betekenis en funksionering en die konsekwensies daarvan vir die kind in die erediens

\subsubsection{Wat is erediens?}

Vir Van der Leeuw is erediens slegs moontlik omdat God dit gegee bet. Erediens is daarom vir hom 'de door God geschonken vorm van omgang met Hem. God spreekt tot de mensch en geeft hem de moed, de vrijmoedigheidt om tot Hem te spreken' (Van der Leeuw 1946:45).

Beide Hoenderdaal en Golterman le klem op die feit dat erediens 'n byeenkoms van 'n Christelike gemeente is en dat dit in die erediens om die eer van God gaan. 'Eredienst is het complex van woorden en handelinge waarin de christelike gemeenschap het haar geschonken geloof vertolkt, ten einde daardoor bij te dragen tot de aanbidding Gods' (Hoenderdaal 1977:39).

De Wet (1983:2) het die erediens beskryf as:

'n Onderlinge byeenkoms van die gemeente wat deur die kerkraad vasgestel is, sodat die gemeente in die openbaar met God in ontmoeting kan tree. Met erediens word dan bedoel: die totaliteit van woorde en handelinge wat tydens hierdie byeenkoms voltrek word, as vertolking van die geloof wat die gemeente ontvang het en steeds weer opnuut moet ontvang. Hierdie woorde en handelinge word gespreek en voltrek tot vermeerdering van God se eer en tot nakoming van die diens wat Hy van ons vra. Dit is 'n gesprek tussen God en die gemeente waarin twee hoofmomente onderskei moet word, naamlik die spreke en handelinge van God deur sy sigbare en onsigbare woord en die antwoord van die gemeente deur belydenis, gebed en sang.

Die mees volledige resente definisie van die erediens tref ons by Dressel (1988:7) aan. Vir hom is erediens:

Die samekoms van die gemeente (met die oog op die saam-doen), waarin die dinamiek van Gods Woord plaasvind en waarin die gemeente geleentheid kry om op die dinamiek van Gods Woord te reageer in aanbidding, lofprysing, geloofsbelydenis, skuldbelydenis (verootmoediging), deelname aan en viering van die heil(sakrament), gemeenskap, gebed, offergawes en diensbetoon in en buite die samekoms. Alles geskied tot eer en verheerliking van die drie-enige God, tot opbou van die gelowiges en onder leiding en toesig van die ampte. 
Deur soos Dressel slegs te praat van die dinamiek van God se Woord, of deur slegs te praat van die verkondiging wat sentraal staan in die erediens, kan die erediens in baie willekeurige vorme ingeklee word. In ons omskrywing van die erediens sal dit daarom nodig wees om telkens te se dat die erediens 'n geleentheid is waar die verkondiging van die Woord in die vorm van prediking sentraal staan.

Uit bogenoemde definisies, met die oog op verdere bespreking kan die volgende grondstellings ten opsigte van die erediens gemaak word:

- Die erediens se oorsprong is in God geleë;

- In die erediens spreek en handel God deur sy Woord en Gees met sy gemeente;

- Die gemeente antwoord op die Woord van God;

- Die erediens vind plaas tot eer van God, tot opbou en uitleef van die gemeente se geloof en tot toerusting van die gemeente vir hulle dienswerk in die wêreld;

- Dit is 'n byeenkoms van 'n Christelike gemeente wat saamgestel is uit 'n groot verskeidenheid lidmate van 'n bepaalde gemeente;

- Dit is 'n ordelike byeenkoms wat bestaan uit bepaalde liturgiese elemente met die prediking as die 'hoofelement';

- Dit is ' $n$ byeenkoms wat onder leiding van en in opdrag van die kerkraad plaasvind.

\subsubsection{God is die middelpunt van die erediens}

In die Ou-Testamentiese erediens was dit God self wat opdrag gegee het om erediens te hou en dit is Hyself wat bepaal het hoe die erediens ingerig moes word. In die Nuwe Testament staan God se offer in Jesus Christus in die middelpunt van alles. Dit is God self wat met sy Gees mense deel gee aan die heil wat gekom het deur Jesus Christus. Hierdie heil wil God in die besonder aan die mens gee daar waar die gemeente Hom in die erediens ontmoet. 'Elke liturgie-viering draagt iets in zich om de grote worsteling van God om het behoud, de reddinging van de mensen, van de aarde, van zijn creatie, zijn schepping' (Vrijlandt 1987:6). In die erediens is dit in werklikheid die ewige en die almagtige God wat die mens kom 'dien'.

Op grond van God se 'diens' dien die gelowige God in die erediens en is die erediens daarom altyd tot eer van God en tot heil van die mens.

Hierdie beskouing van die erediens bring noodwendig mee dat God die eintlike middelpunt, die oorsprong, die handelende subjek van die erediens is. Alles wat die mens doen en bydra, is maar ' $n$ antwoord hierop, ' $n$ resonans van wat God in Christus gedoen het. Daarom is dit in der waarheid 'n diens tot eer van God. Dit is duidelik dat die erediens meer ' $n$ ontvang is as om self te gee. Voordat die mens 
gee, ontvang hy God se genade, liefde, verlossing, vertroosting en geloof. In die gesprek rondom die kind se teenwoordigheid in die erediens is die primêre vraag daarom nie of die kind kan verstaan wat in die erediens gebew nie, maar of hy kan ontvang wat God in die erediens vir hom wil gee. Aangesien dit die wil van God is dat alle mense deel moet hê aan sy heil, is dit wat Hy in die erediens gee ook volkome bedoel vir kinders. Die tweede vraag is nie hoe kan die kind in die erediens behaag word nie, maar hoe kan God deur mense, in hiendie verband deur kinders, in die erediens geëer word. Sonder teëspraak sal elkeen erken dat kinders ten volle in staat is om God in die erediens te eer.

\subsubsection{Die erediens vind plaas met die oog op geloof en diens}

Soos reeds in die vorige paragraaf aangetoon, is die erediens heilsbemiddelend van aard, bedoelende daarmee dat dit 'n besondere middel is wat God wil gebruik om aan mense, deur die werking van die Heilige Gees, aan die verlossing in Jesus Christus deel te gee.

Aan hierdie heil kry 'n mens deel deur die geloof (Heidelbergse Kategismus, vraag en antwoord 65 ). Ons wil daarom dat die kind in die erediens in die eerste plek sal glo en nie soseer verstaan nie. Dikwels word gest dat kinders die prediking en die ander gebeure in die gewone erediens nie kan verstaan nie en daarom moet daar vir hulle afsonderlike eredienste gehou word. Hier word verstaan te veel gesien as 'n suiwer kognitiewe aktiwiteit om alles as logies te beleef. As dit die kriteria sou wees sou die volwassenes ook die erediens met sy inhoud moes afskryf, want die waarheid van God, soos geopenbaar in Jesus Christus, is net nie 'vatbaar' langs die weg van die gewone kognitiewe denke nie.

Nou het ons gesien dat in sowel die erediens as die prediking daar ander aksente en momente is as die blote verstandelike kennis en die intellektuele verstaan. Daar is immers ook die bewuswording van die teenwoordigheid en genade en liefde van God. Daar is die invoeling van die ontmoeting met Hom en die wete van die onbegryplike vryspraak van die sonde. Die diepe geheim van God en sy werk wat in die erediens verwoord en gevier word, en wat in die prediking op baie maniere verduidelik word, kan die kinders nie verstaan nie, maar hulle word daardeur geraak, verander en opgebou. Daarom, al verstaan kinders nie alles nie, het hulle 'n aanvoeling van egte geloof, liefde en lewe, van warmte en bevryding. Al kan hulle nie alles verstandelik ver. 
staan nie, kan hulle dit tog eksistensieel beleef en kan hulle God met oorgawe liefhê en Hom prys en aanbid.

(Barnard 1988:359)

Aangesien die Heilige Gees, wat self God is, die geloof gee, is dit 'n volkome moontlikheid dat ook kinders se geloof in die erediens gewek en versterk kan word. Dit is juis hier waar Roux se bewyse rondom die moontlike religieuse potensiaal van die kind besondere waarde het.

Die erediens het 'n besondere karakter van diens. Dit is die plek waar God sy gemeente 'dien', maar ook die plek waar die gemeentelede God dien, mekaar dien en toegerus word vir hulle dienswerk in die wereld. Die diens aan God in die erediens geskied deur die gemeente se teenwoordigheid in die erediens en deur hulle antwoord op die Woord van God. Slegs die teenwoordigheid van 'n gemeentelid in die erediens is al 'n belydenis opsigself. Deur sy teenwoordigheid in die erediens bely die gemeentelid indirek dat hy sy heil van God verwag. Hy bely dat hy van God wil ontvang en vir God wil gee. Hy bety dat hy deel is van God se volk en daarom, soos dit God behaag, ook saam met hulle wil verkeer. Hierdie diens en belydenis kan die kind ook aan God bring as hy saam met sy ouers in die erediens teenwoordig is. Op grond van die verbond is die kind ook geroepe om God met woord en daad te dien. Net soos die volwassene besit die kind nie van nature die vermoë om God te dien nie. Hierdie vermoë moet God vir Hom gee. Hy moet ook toegerus word om dit te doen. Hierdie toerusting wil God ook aan die kind in die erediens gee en daarom verwag $\mathrm{Hy}$ ook die kind in die erediens, die plek waar $\mathrm{Hy}$ in die besonder gelowiges wil toerus vir hulle dienswerk in die wêreld. In die erediens dien die gelowiges ook mekaar. Hier kry die ouers geleentheid om dienswerk te verrig ten opsigte van hulle kinders. Hulle is geroepe om hulle kinders tydens en na die erediens te begelei. As verbondsouers is hulle geroepe om die inhoud van die prediking en die betekenis van elke liturgiese element met hulle te bespreek en aan hulle te verklaar waar moontlik. Veral deur begeleiding maak ouers die erediens 'n ten volle moontlikheid vir hulle kinders. Die kind se teenwoordigheid in die erediens saam met sy ouers bied vir hom onmeetlike sekuriteit en gebongenheid. Vir die kind is dit sekuriteitgewend om te ervaar dat hy en sy ouers en sy familie saam voor die aangesig van God kan verskyn en saam in sy diens kan staan. 'n Erediens op 'n ander plek en tyd as dié van die ouers beteken vir die kind die prysgawe van hierdie besondere geborgenheid en sekuriteit. Hierdie geborgenheid en sekuriteit, veral omdat die kind op ' $n$ bepaalde stadium God in sy ouers sien (Beukes 1983:133), beteken vir die kind waarskynlik meer as 'n erediens weg van sy ouers waar hy wel alles sogenaamd 'verstaan'. 
Die Heilige Gees se 'gee' van geloof aan die erediensgangers en hulle toerusting met die oog op hulle dienswerk in die wêreld, geskied op 'n besondere wyse. Dit geskied in die erediens deur die die sigbare en onsigbare woordbediening. (Heidelbergse Kategismus, vraag en antwoord 65). Hierdie woordbediening moet na inhoud en vorm sodanig wees dat die hoorders dit verstaan. Dit is opvallend dat die eerste prediking na die uitstorting van die Heilige Gees in die taal van elke teenwoordige was (Hand 2:6-8). Hoewel dit in die erediens nie in die eerste plek gaan om verstaan nie, maar om geloof, sal ons altyd moet onthou die geloof word juis gewek deur die verkondiging wat in 'n 'verstaanbare' vorm geskied. Die verkondiging sal daarom na vorm en inhoud sodanig moet wees dat die grootste moontlike gedeelte van die gemeente daarby betrokke kan wees.

Tradisioneel bestaan die erediens uit 'subjektive und objektive Elementen' (Haendler 1957:159). Kuyper beskryf die erediens as bestaande uit een actus a parte Dei, en een actus a parte populi (Kuyper 1909:515). Hoewel daar nie 'n rigiede skeiding tussen God se acti en die mens se acti in die erediens getrek kan word nie, is die verdeling tussen God se handelinge en die mens se antwoord in die erediens ' $n$ heeltemaal aanvaarde verdeling en ' $n$ handige gegewene om mee te werk.

God se besondere handelinge in die erediens voltrek hulle deur middel van die votum en die seëngroet, die wetlesing, die genadeverkondiging, die Skriflesing, die prediking en die seën. In die lig van vorige stellings sal elkeen van hierdie gedeeltes van die erediens so ingeklee moet word dat die grootste gedeelte van die gemeente, dit wil sê ook die kinders, daarby betrokke kan wees.

\subsubsection{Die gemeente se reaksie op die handelinge van God}

God se koms, sy handelinge met die mens in Christus deur die Heilige Gees in die erediens, het tot gevolg dat die mens reageer, antwoord op die handelinge van God. Hierdie antwoord moet plaasvind met die mens se hart, hand en verstand, sy hele wese. Dit moet ook plaasvind deur almal wat in die erediens teenwoordig is. Dit moet deur elkeen plaasvind volgens sy eie vermoëns en volgens sy eie aard binne die grense wat deur die bepaalde gemeente se liturgie daar gestel word. Dit beteken in feite dat die erediensvoorganger telkens 'n deeglike situasie-ontleding van die mense wat in die erediens teenwoordig is, sal moet maak. Hy sal moet vra na die Bybelse antropologie, die besondere fase waarin verskillende lidmate hulle bevind en die besondere kenmerke van die mens van 'n bepaalde tyd en 'n bepaalde plek. 'n Sinvolle situasie-ontleding sal noodwendig daartoe lei dat ook die kind in sy besondere fase en situasie in die oog van die liturg sal kom en met hom ook rekening gehou sal word wanneer die gemeente antwoord moet gee deur gebed, sang. skuldbelydenis, geloofbelydenis en gee van offergawes. 
3.4.5 Die erediens is 'n ordelike byeenkoms met 'n bepaalde vorm en bepaalde elemente

Hoenderdaal $(1977: 26,27,110)$ het gepleit vir 'n erediens waar die grootste moontlike vryheid, spontaniteit en natuurlikheid heers. Hierdie komponente mag egter nie daartoe lei dat die erediens ontaard in 'n ordelose, chaotiese byeenkoms nie. Het kan noch mag aan den Dienaar overgelaten dat hij naar gril en inval nu eens zoo en dan weer zoo, in deze handelingen voorga en leide (Kuyper 1909:517). Natuurlikheid en spontaniteit hef nie noodwendig die goeie orde op nie. Die gegewens uit die Skrif getuig juis dat die erediens ordelik verloop het. Ordelikheid is een van die vereistes wat Paulus aan die erediens gestel het (1 Kor 14). Dit is nie waar, soos dikwels beweer word, dat 'n bepaalde orde die werking van die Heilige Gees in die weg staan nie. Die uitsprake oor die orde in die erediens staan juis in 1 Korintiërs 14 in die konteks waar daar gehandel word oor die bepaalde charisma wat die Gees aan mense gee. Die gebruik van mense en middele in God se diens, hef nie die verlangde orde op nie. Wanneer oor die orde in die erediens gepraat word, sal daar noodwendig aan die volgende sake aandag gegee moet word:

- Watter elemente mag in die erediens gebruik word?

* In watter volgorde moet hierdie elemente in die erediens geplaas word?

- In watter vorm moet die elemente gegiet word?

Net soos in die Ou Testament word daar in die Nuwe Testament nie 'n bepaalde erediensvorm voorgeskryf nie. In beide die Ou en die Nuwe Testament word daar bepaalde eredienselemente genoem sonder dat dit rigied voorgekryf word. Beide die vroeẽ Christelike Kerk en die kerkhervormers het geoordeel dat in die lig van die Bybelse gegewens, die volgende elemente in die erediens behoort voor te kom: votum en seëngroet, sang, wetlesing, skuldbelydenis, genadeverkondiging, geloofbelydenis, Skriflesing, prediking, gebed, bediening van die doop en die nagmaal, seën en offergawes (Barnard 1981:257-376). Die Nederduitsch Hervormde Kerk het ook geoordeel dat in die lig van die Skrif, hierdie elemente in die erediens gebruik moet word (NHKA 1987:8-53). Die vraag kan tereg gevra word of dit altyd nodig is om al die elemente in die erediens te gebruik? Christus self het net opdrag gegee vir die verkondiging van die Woord, die bediening van die sakramente en die gebed. In die meeste kerke bestaan daar reeds die gebruik om met besondere eredienste 'n liturgie te volg waar net Skriflesing, prediking, gebed en sang voorkom met inwerking van die ander elemente in die genoemde vier elemente. Dit is belangrik om daarop te let dat in die Nuwe Testament, in die vroez Christelike Kerk en by die Reformatore, die prediking in die middelpunt van die erediens gestaan 
het. In die lig van ons tema sal dit beteken dat die genoemde eredienselemente met die klem op die prediking ook in die erediens met kinders sal moet funksioneer. Nog die Nuwe nog die Ou Testament gee 'n vaste voorskrif in watter volgorde die verskillende eredienselemente geplaas moet word. Volgens die Reformatore is verskillende liturgiese diensordes met verskillende plasings moontlik. In die Nederduitsch Hervormde Kerk en in die Nederduitse Gereformeerde Kerk bestaan daar 'n groot aantal diensordes waaruit met elke erediens gekies kan word (kyk die verskillende diensordes in die twee genoemde Kerke se diensboeke). Die groot verskeidenheid diensordes bied die moontlikheid om miskien beter by die kind uit te kom as met die enkele diensorde wat vroeër gebruik is. Daar behoort selfs oorweging gegee te word aan die moontlikheid om diensordes te ontwerp wat die volwassene en die kind gelyktydig beter in die erediens sal kan akkommodeer.

Wat die inkleding van die eredienselemente betref, word in die Bybel ook nie vaste voorskrifte gegee nie. Verskillende liturgiese gebruike word genoem, sonder om noukeurig voor te skryf hoe dit aangebied moet word.

Ook in die vroeë Christelike Kerk en die Reformatoriese Kerke was daar nie voorskifte dat elke eredienselement altyd op dieselfde wyse bedien hoef te word nie. Dit is opvallend dat in die Diensboek van die Nederduitsch Hervormde Kerk van Afrika nie melding gemaak word van hoe die verskillende elemente ingeklee moet word nie. Uit die notules van hierdit Kerk se Algemene Kerkvergadering blyk dit dat ook nie baie besluite geneem is oor die vormgewing van die verskillende eredienselemente nie. Die Kerk beskou hierdie saak waarskynlik vandag nog, soos die Reformatore, as 'n middelmatige saak. Die feit dat daar nie vaste voorskrifte bestaan ten opsigte van die inkleding van die verskillende elemente nie, laat die moontlikheid dat die elemente van die erediens so ingeklee kan word dat dit beide kind en volwassene gelyktydig in die erediens kan betrek.

\section{Die kind as erediensganger}

Die erediens is 'diens' van God aan mense en diens van mense aan God. Hierdie mense is bepaalde mense. Hierdie mense kan alleen ten volle betrokke wees by die erediens as daar met hulle rekening gehou word. Voor die erediens se inhoud geskep en ingeklee word, moet daar eers 'n deeglike situasie-ontleding gedoen word van die mense wat in die erediens teenwoordig gaan wees. Die liturg sal ook deeglik rekening moet hou met onder andere die kinders wat in die erediens teenwoordig is.

Wanneer gepraat word oor die kind in die erediens, sal daar ten minste aandag aan die Bybelse antropologie, algemene kenmerke van kinders en die besondere fases van kinders gegee moet word. Elkeen van hierdie aspekte is 'n studie op 
sigself en gevolglik sal slegs die vernaamste aspekte puntsgewys aangestip word.

\subsubsection{Die Bybelse antropologie}

In die Bybel tref ons nie 'n uitgewerkte leerstuk oor die kind aan nie. Die kind word in die Bybel beskryf as mens in die volle sin van die woord. Dit bring mee dat die Bybelse leer oor die mens net so van toepassing op die kind gemaak kan word.

- Soos die res van die skepping is die kind deur God geskep en behoort hy in die eerste plek aan God. Omdat hy aan God behoort, bemoei God Hom op 'n besondere wyse met hom en is al God se gawes ook vir hom bestem. Omdat die kind aan God behoort, moet hy in diepe afhanklikheid van God leef en gehoorsaam wees aan God.

- Die kind is geskep uit die stof van die aarde. As sodanig is hy 'n nietige verganklike mens van wie nie te veel verwag kan word nie.

- Die kind is 'n psigosomatiese eenheid. Hy is liggaam en gees. Hy het gevolglik liggaamlike en geestelike behoeftes.

- Die kind is geskep na die beeld van God. Volgens die Kategismus beteken dit dat hy is so geskep is dat hy God kan ken, kan dien en in ewige gemeenskap met Hom kan leef (Heidelbergse Kategismus, vraag 6). Deur die sondeval het die mens die besondere eienkappe as beelddraer van God verloor. Dit waaraan die mens nie kon voldoen nie, het Jesus Christus voldoen. In die Nuwe Testament word Hy die beelddraer van God genoem (Kol 1:15). Deur Jesus word dit daarom weer ten volle moontlik vir die kind om God lief te he, te ken, te dien en in gemeenskap met Hom te leef.

- God het die mens geskep om te heers oor die skepping (Gen 1:26; Ps 8:6). Op grond hiervan is die mens bestem om wetenskaplike, navorser en arbeider te wees. Om in die wêreld met die materiële werklikheid besig te wees, is daarom nie sonde nie, maar opdrag van God.

- Die kind is sondaar. Hy het ten volle deel aan die sonde van Adam en Eva (NHKA 1983:56). Hy is van nature ongehoorsaam aan die Woord van God. Hy besit ook nie die vermoë om te onderskei tussen goed en kwaad nie. As gevolg van sy sondige natuur is al die versoekings op sy pad vir hom 'n wesenlike gevaar. Die erns maak met die kind en sy natuurlike vermoëns, bring noodwendig mee dat hy nooit te hoog aangeslaan mag word nie.

- $\mathrm{Al}$ is die kind sondaar buite sy wete, bly hy nog aanspreeklik vir sy optrede. Die gelowige kind het deur Jesus Christus 'n nuwe skepsel geword wat nie alleen die verantwoordelikheid het om gehoorsaam aan God te wees nie, maar wat ook deur die krag van die Heilige Gees daartoe in staat is. 
- Die kind wat sondaar is, is tegelyk begenadigde sondaar. Jesus Christus het vir al sy sonde betaal, die dood vir hom oorwin en bom kind van God gmaak. Deur Jesus Christus het die kind ten volle deel aan Christus en aan al sy weldade. (Heidelbergse Kategismus, vraag en antwoord 74). Die kind het ook deel aan die verbond en tydens sy doop is sigbaar aan hom bevestig dat God sy vader is, dat Jesus Christus hom verlos het van al sy sonde, dat die Heilige Gees ook aan hom gegee is en dat hy ook lidmaat van die kerk is. Elkeen wat besef wie en wat die kind in Christus is, sal die kind nooit te laag skat nie.

- Die jeug van vandag is die kerk van more. Hierdie saak word veral in die Ou Testament beklemtoon. Die jongmanne is die volk se soldate. Die jongdogters is die moeders in wording. Verwaarlosing van vandag se jeug, lei tot more se misoes.

- Die dae van 'n mens se jeug word beskryf as besondere dae. Dit is dae van lewenslus, krag, entoesiasme, eksperimentering ensovoorts (Pred 11:9; Spr 20:29; 1 Sam 14 en 17; 1 Kon 12; Tit 2:4-6; 2 Kron 34:3v). Die jeug se besondere aard mag egter nie sy geloof en lewe in diens van God ophef nie. Die jeug se besondere aard bring besondere vrae en probleme na vore. Die kerk moet die jeug en sy besondere leefwereld ken en hom op 'n sinvolle wyse deur sy besondere lewensfases lei.

\subsection{Algemene kenmerke van kinders}

Alhoewel elke kind uniek is en kinders daarom meer anders is as eenders, is daar tog 'n aantal karakteristieke van kinders wat in 'n baie groot mate ooreenstem.

S E Olivier beskryf die enersheid van kinders as geleë in die volgende aspekte: kindwees impliseer volwasse-wordend wees, die kind is intensionaliteit, die kind hunker na geborgenheid, die kind is spelend in die wêreld, hy beleef slegs die sinvolle as positief, hy het ' $n$ bepaalde wyse waarop hy leer en bevind hom in 'n bepaalde lewensfase (Olivier 1985:246-257). Hierdie aspekte wat Olivier van toepassing gemaak het op die kategese, geld in 'n baie groot mate ook vir die erediens. Dit wat relevant vir die erediens is, sal bespreek word.

- Die kind is volwasse-wordend. Omdat die kind nog nie volwasse is nie, kan hy nie selfstandig optree nie en kan hy gevolglik ook nog nie verantwoordelike besluite neem nie. Die kind moet begelei word om die inhoud van verantwoordelike besluite te ken en moet dan gehelp word om hierdie besluite in sy lewe van toepassing te maak. 
- Die tind is geen speelbal in die hand van die volwassene nie. Hy is medebepalend. 'Niemand kan 'n kind laat leer wat hyself nie wil leer nie' (Olivier 19885:249). Deur goeie onderrig kan nie verseker word dat 'n kind leer nie, maar deur swak onderrig word defnitief verhinder dat by leer.

- Die kind het baie groot behoefte aan geborgenheid op sy lewensgang. In die erediens word hierdie geborgenheid deur die atmosfeer geskep. Die belangrikste skeppers van die atmosfeer is ongetwyfeld die persone saam met wie hy in die erediens sit en die voorganger van die erediens. Laasgenoemde is veral belangrik omdat die kind hom slegs laat leer deur iemand wat daarin slaag om sy vertroue te wen en wat vir hom 'n gevoel van geborgenheid gee.

- Die kind is voortdurend besig om te beleef. Slegs dit wat vir hom sin maak, beleef hy as positief. Dit wat in die anbieding vir die kind nie sinvol is nie, gaan verlore afgesien van die hoeveelheid herhalings daarvan. Sinvolle aanbieding na inhoud en vorm word onthou, selfs na 'n eenmalige blootselling. Die kind se belewenis lę veral op die vlak van die kognitiewe en die affektiewe.

Indien hy gevoelsmatig beleef dat die inhoud en die wyse van aanbieding vir hom gevoelsmatig gerusstellend, vertroostend en stabiliserend van aard is, beklee hy dit met positiewe sin en rig hy homself intensioneel met openheid tot verdere verkenning. Word die kind nou op gereelde basis onderwerp aan onderrig wat kognitief bokant sy vuurmaakplek is, bou die kind 'n bepaalde ervaringbesit op ten aansien van die inhoud as synde nutteloos vir hom. So 'n kind onttrek en wil homself nie intensioneel rig nie. Hy laat hom nie verder onderrig nie.

(Olivier 1985:251)

- Kinders bevind hulle in verskillende lewensfases. Hoewel hierdie fases nie in waterdigte kompartemente ingedeel kan word nie, het elke fase tog besondere kenmerke. Met die oog op ons bespreking werk ons met 'n kombinasie van die indeling van Landman \& Olivier. Hulle deel kinders in in die eerste lewensjare (1-4 jaar), die vroeë kinderjare (5-7 jaar), die middel kinderjare (8-10 jaar), die laat kinderjare (11-13 jaar) en die adolessent (13-18 jaar) (kyk Beukes 1983:130). Slegs enkele aspekte van elke fase wat relevant is ten op sigte van die kind se bywonig van die erediens, sal bespreek word. 
- Gedurende die eerste lewensjare is die kind en sy moeder feitlik 'n eenheid. Hy bring die grootste gedeelte van sy tyd saam met haar deur. Hierdie jare is van sy belangrikste vormingsjare. Gedurende hierdie jare is hy volgens Roux se navorsing reeds vatbaar vir godsdiensonderrig. Die kind se grootste behoefte op hierdie stadium is liefde en geborgenheid. Veral die moeder van die kind in hierdie fase sal onderrig oor die erediens moet ontvang om dit weer aan haar kind oor te dra. In hierdie fase, soos in alle ander fases, sal die kind besondere geborgenheid van sy ouers in die erediens moet ervaar.

- In die vroeë kinderjare stel die kleuter hoofsaaklik belang in die konkrete. Slegs die hier en die nou het vir hom betekenis. Hy konsentreer op die bekende en nie op die belangrike nie. Hy dink met sy hart en nie met sy verstand nie. Sy begripswêreld is net so breed soos sy ervaringsveld. Hy het geen begrip van tyd nie - Moses en Jesus het vir hom byvoorbeeld in dieselfde tyd geleef. Hy is 'n baie sterk nabootser en gevolglik word sy godsdiens hoofsaaklik bepaal deur die godsdiens van sy opvoeders. Hy gaan selfs so ver dat sy voorstelling van God gelyk is aan die voorstelling wat hy van sy ouers het (Van Wyk 1976:9). Net soos in die vorige fase is sy sterkste behoefte die na liefde en geborgenheid.

- Die kind in die middel-kinderjare se eienskappe stem in 'n baie groot mate ooreen met die kind in die vorige fase. Die volgende aspekte kom egter by: Hy is baie sterk bewus van gedragkodes en reëls en aanvaar sonder meer die norme wat sy ouers aan hom voorhou. Hy is baie sterk geheg aan sy huisge-sin maar ook aan die groep. Hy is baie energiek.

Uit hierdie kort besknywing is dit baie duidelik dat daar 'n baie groot verskil tussen die kinders in hierdie eerste drie fases en die volwassene bestaan en hulle nie sonder meer op dieselfde wyse as die volwassene in die erediens begelei kan word nie.

- In die laat-kinderjare beweeg die kind baie sterk na die volwassene. Hy verstaan nou tydordes. Hy begin abstrak dink. Hy raak krities ingestel. Hy is baie sterk groepgebonde. Op hierdie stadium van sy lewe vereenselwig hy hom met bepaalde normes.

- Die adolessente fase is die kritiese fase by uitnemendheid. Die ontdekking van die self, die liggaamlike ontwikkeling en die teenstrydighede in die lewe lei daartoe dat die tiener se lewe gekenmerk word deur groot onsekerheid. Op hierdie statium dink die tiener volkome logies en abstrakte denke is nie 
meer vir hom vreemd nie. Sy intrede in die wêreld van die logiese denkers het tot gevolg dat hy baie krities ingestel is teenoor alles en slegs dit aanvaar wat vir hom logies is. Hy het 'n baie sterk drang na vryheid. Die norme van sy ouers en ander opvoeders aanvaar hy nie sonder meer nie. Die kriteria van die groep is vir hom belangriker as dié van sy ouers. Saam met die groep is eksperimentering, selfs op die vlak van die godsdiens, nie vir hom vreemd nie. Besondere belangstelling in die teenoorgestelde geslag is op hierdie stadium doodnatuurlik (vir meer detail besonderhede oor die verskillende fases kyk Beukes 1983:131-146; Greyling 1942:52-60).

\section{AFLEIDINGS}

- Uit die Bybelse, historiese en ander gegewens in verband met die erediens blyk dit dat kinders van alle ouderdomme in die gewone erediens teenwoordig behoort te wees.

- Uit dieselfde gegewens, maar in die besonder uit die gegewens van die menswetenskappe, blyk dit dat vanweë kinders se besondere aard, die erediens so ingerig moet word, dat daar met hulle rekening gehou word.

- Tussen volwassenes en kinders in die eerste drie lewensfases (dit is kinders tot ongeveer 12 jaar) is 'n baie groot verskil. Dit het tot gevolg dat hulle en volwassenes nie op dieselfde wyse in die erediens betrokke kan wees nie.

\section{AANBEVELINGS}

- Die kinders woon die gewone eredienste van die gemeente by.

- Die gewone erediens word so ingerig dat die kinders so ver as moontlik by die erediens betrokke kan wees.

- Met die oog op die besondere behoeftes van die kinders word 'n aantal eredienste per jaar, met 'n aangepaste liturgie gehou, waar die inhoud en die vorm van die erediens sodanig is dat dit in die eerste plek gerig is op die kinders in die eerste lewensfases, veral die kinders tussen vyf en twaalf jaar.

6. INKLEDING VAN DIE GEWONE EREDIENS MET DIE OOG OP TEENWOORDIGHEID VAN KINDERS

- Omdat die erediens die hart van die kerk se bediening is, word die erediens as die kernaktiwiteit geidentifiseer ten op sigte waarvan die gemeente onderrig behoort te ontvang. Die gemeente behoort deeglik toegerus te word in verband 
met die wese, aard en die doel van die erediens. In elke gemeente behoort moeite gedoen te word om die kinders so te begelei dat hulle sal verstaan waarom die erediens noodsaaklik is, waarom die erediens uit bepaalde elemente bestaan, wat die betekenis van elke element is, waarom die elemente op verskillende plekke in die erediens geplaas kan word, waarom die elemente op verskillende wyses ingeklee kan word, waarom verskillende diensordes gebruik word en in die besonder hoe aan elke deel van die erediens deelgeneem behoort te word. Hierdie onderrig sal deur die ouers en die kategete moet geskied met gebruikmaking van die inhoude wat deur die kerk voorsien word. Bleij (sa: 9) het gepleit dat kerk, ouers en skool in hierdie verband saam hande sal vat.

- Om die kinders sinvol in die erediens te betrek, moet nie slegs 'n gedeelte van die erediens ingerig word met die oog op hulle nie. Dit is nie voldoende as net aan die einde 'n kort opsomming van die preek vir die kinders gegee word of deur net die kinders afsonderlik aan te spreek in die erediens nie. Die erediens sal in totaliteit beplan moet word met die oog op die beoogde doel vir al die mense wat in die erediens teenwoordig is. Dit vra 'n besondere aanpak van elke erediens wat ons 'n geheelstrategiebeplanning kan noem. Hierdie geheelstrategiebeplanning bestaan uit die volgende komponente: Eksegeties-teologiese arbeid van die teks (ETA), doelwit formulering (DF), teikengehoorontleding (TO) en praktiese inkleding (PI) van elke deel en element van die erediens.

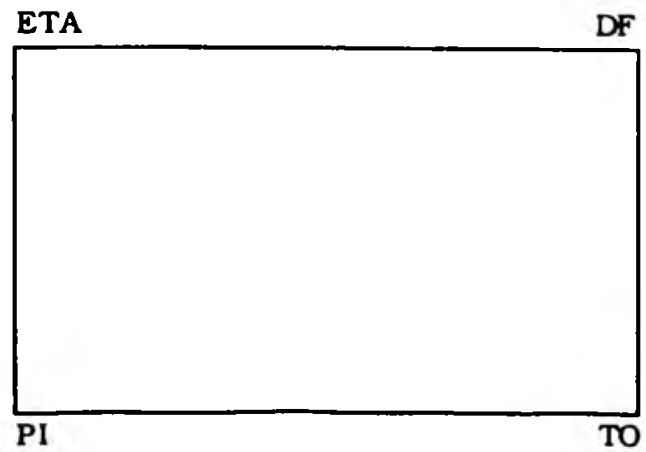

In feite beteken dit: Die eksegese en die teologiese werk van die preek vind normaalweg plaas. Hierna neem die liturg die mense wat in die erediens teenwoordig gaan wees in oennskou en maak 'n ontleding van bulle. Veral op die volgende sal gelet moet word: die aantal verskillende ouderdomsgroepe, die akademiese peil van elke groep, elke groep se kennis van die Woord, hulle gesindheid ten op sigte van 
God en sy diens, hulle kerklike betrokkenheid en die kenmerke van die fase waarin die betrokkenes hulle bevind. Hierdie ontleding van die teikengehoor hoef uit die aard van die saak nie met elke preek plaas te vind nie. 'n Deeglike ontleding kan vir ten minste ' $n$ jaar in 'n gemeente gebruik word. Hierna, met die teologiese werk as vertrekpunt, word die kernboodskap van die teks neergeskryf en omskryf in 'n breë doelstelling. Hierdie doelstelling word met die oog op die persone wat in die erediens teenwoordig gaan wees, omskryf in fyner doelwitte. Die prediker kan vir homself die vraag vra: wat moet die mense wat in die erediens teenwoordig is na afloop van die preek weet, wees, en kan doen. Anders gestel: oor watter kennis, gesindheid en vaardigheid moet die erediensgangers na afloop van die erediens beskik. Hierna volg die praktiese inkleding van die preek. Die preek word uitgewerk en voorberei met die oog op die realisering van die doelwitte, so ver as moontlik, ten opsigte van almal wat in die erediens teenwoordig gaan wees. Hierna, met die preek en sy doelwitte en die teenwoordiges van die erediens in die oog, word die liturgiese orde gekies en elke element van die erediens na vorm en inhoud ingeklee.

- Die geheelstrategiebeplanning van die erediens beteken dat daar noodwendig ten volle rekening gehou sal word met die kinders wat in die erediens teenwoordig is. As met die kinders van al die verskillende fases rekening gehou word, sal die volgende algemene sake deurlopend in die oog gehou moet word.

- Die vlak van die preek, die gebed en al die ander elemente sal nie so geleerd as moontlik nie, maar so verstaanbaar as moontlik moet wees. Oor die algemeen blyk dit dat sinvolle inhoude wat op 'n elementêr-verstaanbare vlak aangebied word, nie steurend is vir mense wat normaalweg op 'n hoë vlak kommunikeer nie.

- Die inhoud van elke deel van die erediens sal van so aard moet wees dat die boodskap deur die grootste moontlike deel van die erediensgangers verstaan' sal word.

- Met die verskillende fases van die kinders in die oog, sal konkrete inhoude in plaas van abstrakte begrippe gebruik moet word. Die erediens sal deurgaans 'n boodskap moet bring wat vir beide die tiener en die kind in sy klein-kinderfase geborgenheid by God bied. Die erediens sal vir die tiener in sy soeke na die waarheid die nodige antwoorde moet gee. Die erediens sal vir hom ook antwoord moet gee op die teenstrydighede van die lewe wat hy daagliks ondervind.

- Die liturg sal moet inkom in die leef en denkwêreld van die kind. Die liturgiese vormgewing sal moet geskied in die taal van volwassenes en kinders. Die voorbeelde in gebed en prediking sal nie net moet kom uit die wereld van die volwassene nie maar ook uit die werreld van die kinders. Die aanbieding in die ere- 
diens sal na vorm meer pastoraal as didakties van aard moet wees. Selfs didaktiese inhoude behoort gesprekmatig oorgedra te word. Die kind luister as met hom mooi gepraat word, maar nie wanneer vir hom geskreeu of vir hom 'gepreek' word nie. 'By enige preek, maar veral by preke vir kinders, is die houding van die prediker baie belangrik. 'n Simpatieke, vriendelike, hartlike, liefdevolle en solidêre houding bring die boodskap baie beter tuis by kinders as 'n outoriterre, strakke, vreesaanjaende, koue en gedistansieerde houding' (Barnard 1988:368).

- Die skep van die regte atmosfeer is baie belangrik. 'n Lewende, dinamiese erediens spreek kinders aan. Die atmosfeer moet van so 'n aard wees dat die kind daar tuis voel en lief word om daarheen te gaan. Die atmosfeer moet van so ' $n$ aard wees dat die kind in die erediens geborge voel en oortuig is hier is ook vir my plek en hier wil God, maar ook sy gemeente, met my kommunikeer.

- Die kind se leefwèreld is ' $n$ wèreld waarin media 'n belangrike rol speel en die aanwending daarvan kan 'n groot bydrae lewer om boodskappe aan die kind oor te dra. Regte benutting daarvan kan ook 'n bydrae lewer om groter betrokkenheid van die kind in die erediens te bewerkstellig.

- In kort, die kind moet so ver moontlik by alles in die erediens betrek word.

- Teoloë en opvoedkandiges sal deurlopend moet besin oor 'n kommunikasiestrategie hoe om kinders en volwassenes so ver as moontlik gelyktydig in die erediens te betrek.

\section{AFSONDERLIKE EREDIENSTE VIR KINDERS}

'n Gewone erediens is ' $n$ erediens waar die hele gemeente in die erediens teenwoordig is en in die beplanning en aanbieding van die erediens in gelyke mate met almal in die erediens rekening gehou word. 'n Buitegewone erediens vir kinders is 'n erediens waar die hele gemeente teenwoordig is, maar waar primêr gelet word op die kind en sy besondere behoeftes, veral kinders in die eerste drie genoemde lewensfases, is hier ter sprake.

Indien die geheelstrategiebeplanning in die gewone erediens reg toegepas word, sal daar nie 'n baie groot verskil tussen die gewone en die buitegewone erediens vir kinders wees nie.

Die verskil sal hoofsaaklik geleë wees in die temas wat in die prediking hanteer word en die wyse van aanbieding. Die kind se besondere behoeftes bring noodwendig mee dat daar bepaalde geloofsake is wat hom op 'n bepaalde stadium van sy lewe miskien meer intens raak as vir die volwassene. Hier sal dit veral die doelwitte wees wat sal verskil van die van die erediens waar in gelyke mate met almal in die 
erediens rekening gehou word. Die kategese is die besondere verkondigigsgestalte waar onder andere rekening gehou word met elke fase se besondere 'godsdiensbehoeftes'. Vanweë die beperkte tyd en vanweë die behoefte om bepaalde temas miskien vroeër en miskien meer dikwels te hanteer, bied die buitegewone eredienste vir kinders hiervoor besondere geleentheid. By hierdie geleenthede kan kategese en erediens goed gekoppel word deurdat die bepaalde tema wat in die erediens hanteer word in die kategese verder bespreek kan word. Met hierdie buitegewone erediens vir kinders kan selfs verder gedifferensieer word, en indien dit nodig sou wees kan ' $n$ erediens afgestaan word aan kinders in net een bepaalde fase.

Uit navorsing blyk dit dat bepaalde metodes van aanbieding meer geskik is vir persone in bepaalde fases van hulle lewe as vir ander (Nel 1985:171). Didaktici het die onderrigwyses vir kinders in 'n baie hoë mate tot op 'n bepaalde hoë vlak verfyn. Hierdie onderrigstrategieë en veral die hermeneutiese model van Roux kan die kerk benut sonder om sy eie prinsipiële standpunte prys te gee. Deur dit reeds in die kategese te benut het die kerk indirek verklaar dat hy hierdie strategieê kan en wil benut. Die kerk behoort vir homself uit te maak watter van hierdie strategieë vir hom aanvaarbaar is vir gebruik in die erediens en behoort dan deur die liturg gebruik te word vir die buitegewone eredienste. Die kernvraag waarop antwoord gevind sal moet word is: watter aanbiedinswyses is die beste vir 'n gehoor wat lyk soos 'n gemeente op 'n gewone Sondagoggend? Wat die buitewone erediens vir kinders betref, sal die vraag behoort te wees: watter onderrigwyses is die beste om 'n groep te bereik wat in die besonder saamgestel is uit kinders uit verskillende lewensfases?

Die frekwensie van hierdie buitegewone eredienste vir kinders behoort nie rigied vasgelê te word nie. Aangesien dit gesien word as buitegewone eredienste behoort die getal daarvan nie te groot te wees nie. Elke gemeente se eie aard sal bepaal hoe dikwels hierdie eredienste gehou word. 'n Goeie gebruik sou miskien wees om te volstaan met vier sulke eredienste per jaar in die oggend en miskien 'n paar in die aand waar dan in die besonder gekonsentreer word op bepaalde probleme wat kinders in bepaalde fases ondervind.

\section{SAMEVATTING}

Uit Bybelse en historiese gegewens is dit duidelik dat die kind ten volle deel is van die kerk van Christus en dat die kind gereeld saam met die gemeente in die gewone erediens moet vergader. Uit die menswetenskappe is dit duidelik dat die kind, veral in sy eerste drie lewensfases, so van die volwassene verskil dat hy besondere aandag in die erediens vra. Dit bring mee dat die liturg met elke erediens met die kind in 
die erediens rekening sal hou en dat daar van tyd tot tyd buitegewone eredienste gehou word waar veral met die kind in die eerste drie lewensfases rekening gehou word.

\section{Literatuurverwysings}

Aalbers, B J 1971. Kinderen aan het avondmaal? Kampen: Kok.

Achelis, E Chr 1906. Praktische Theologie. Utrecht: Kemink en zoon.

Barnard, A C 1981. Die erediens. Pretoria: NG Kerk-Uitgewers.

--- 1988. Erediens en prediking met die oog op die bereiking van kinders. NGTT $29 / 4$.

Beukes, M J du P 1983. Kategese: 'n Handleiding vir kategete. Pretoria: Kital.

-- 1987. Vernuwing in die erediens: Praktiese Teologie in Suid-Afrika, 3. Pretoria: NG Kerk-Uitgewers.

.. 1987. Die erediens. Ongepubliseerde diktaatlesings, Universiteit van Pretoria.

Bijlsma, R 1969. Kleine Catechetiek. Nijkerk: Callenbach.

Bleij, W s a. Kinderdiensten voor Zondagschool en Kinderkerk, deel 3. Nijkerk: Callenbach.

Capon, A \& Capon, E 1967. The church and the child towards a Christian upbringing. London: Hodder \& Stoughton.

Coetzee, J J 1987. Kind in die erediens, Die Hervormer, Jaargang 76/4.

De Klerk, B J 1987. Die Heilige Gees en die verhouding Skriflesing, prediking en gebed. Th D-proefskrif, Potchefstroomse Universiteit vir Christelike Hoër Onderwys.

De Wet, J I 1964. Liturgiek 1. Ongepubliseerde diktaatlesings, Departement Praktiese Teologie (Afd A), Universiteit van Pretoria.

Dressel, L C 1988. Wat is die erediens wat vemuwe moet word? Praktiese Teologie in Suid Afrika 6. Pretoria: NG Kerk-uitgewers.

Dreyer, T F J 1989. Poging tot 'n herdefinisie van die prediking binne die raamwerk van die Reformatoriese teologie. HTS 45, 350-369.

Freese, D A 1982. Childrens church a comprehensive how-to. Chicago: Moody Press.

Golterman, W F 1951. Liturgiek. Haarlem: De Erven.

Groenewald, D H 1989. Die kinderdiens in die Nederduitse Gereformeerde Kerk, met besondere verwysing na die kinderpreek. DD-proefskrif, Universiteit Pretoria.

Haendler, O 1957. Grundriss der Praktischen Theologie. Berlin: Alfred Topelmann. Hagenbeek, D S A 1947. De modeme leerkerk, nieuwe richttlynen voor het catechetisch onderwijs. Kampen: Kok. 
Hoenderdaal, G J 1977. Riskant spel, Uturgie in een geseculariseerde wereld. Gravenhage: Boekencentrum.

Jonker, H s a. Liturgische orientatie, gesprekken over de eredienst. Wageningen: Zomer en Keuning.

Kruger, R J 1980. Beginsels en kriteria in kurrikulum ontwerp. Pretoria: HAUM.

Kuyper, A 1909. Encyclopedia der heilige godgeleerdheid, derde deel. Kampen: Kok.

Louw, J D 1973. Die plek van die kind aan die verbondsdis. BD-skripsie, Universiteit van Pretoria.

Muller, J C 1983. Die homelie as wyse van eietydse prediking. DD-proefskrif, Universiteit van Pretoria.

Muller-Fahrenholz, G 1981. Und wehret ihnen nicht, ein ökomenisches pladoyer fur die Zulassung von Kindern zum Abendmahl. Frankfurt: Otto Lembeck.

Nederduitsch Hervormde Kerk van Afrika. Diensboek 1987. Pretoria: Kital.

Nederduitse Gereformeerde Kerk. Algemene Sinode Acta 1978. Pretoria: NG Kerk-Uitgewers.

Nel, M 1985. Moderne ontwikkeling op die terein van die kategese met besondere ver-wysing na die metodiek, in Smuts, A J (red), Die Woord aan die werk oor die kerklied, prediking en kategese. Pretoria: NG Kerk-Uitgewers.

Olivier, M 1985. Die kind in die kategese, in Smuts, A J (red) Die Woord aan die werk. Pretoria: NG Kerk-Uitgewers.

Roux, C D 1988. Woordbediening aan die kind, 'n hermeneutiese verantwoording.

Th D-proefskrif, Universiteit van Stellenbosch.

Treurnicht, A P s a. Sinvolle kerkgang. Kaapstad: NG Kerk-uitgewers.

Trimp, C 1983. De gemeente en haar liturgie, een leesboek voor kerkgangers. Kampen:

Van den Berg.

Van der Leeuw, G 1946. Liturgiek. Nijkerk: Callenbach.

Van Loggerenberg, N T 1982. Kinderdienste. Die Voorligter.

Venter, S 1989. Die posisie van dooplidmate in die Gereformeerde kerke. Ongepubliseerde referaat gelewer tydens interkerklike gesprek oor jeugwerk in die drie Afrikaanssprekende kerke in Suid-Afrika.

Viljoen, D 1989. Paidocommunio. Ongepubliseerde referaat gelewer tydens interkerklike gesprek oor jeugwerk in die drie Afrikaanssprekende kerke in SuidAfrika.

Vrijlandt, M A 1987. Liturgiek. Delft: Meinema. 